\title{
HADARAT IN TUAL CITY MALUKU: THE ROLE OF ARAB AL-KATIRI IN INTEGRATION OF ISLAM AND LOCAL CULTURE
}

\author{
Usman Nomay ${ }^{1}$, Jamain Warwefubun ${ }^{1 *}$ \\ ${ }^{1}$ Institut Agama Islam Negeri (LAIN) Ternate \\ *Corresponding author:jamain@iain-ternate.ac.id

\section{(c) (1) (2)} \\ C 2021 by the authors. Submitted for possible open access publication under the terms and conditions \\ of the Creative Commons Attribution-ShareAlike 4.0 International License (CC-BY-SA) \\ license (https://creativecommons.org/licenses/by-sa/4.0/) \\ doi DOI: http://dx.doi.org/10.30983/fuaduna.v5i2.4969

Received: November 07, $2021 \quad$ Revised: December 21, $2021 \quad$ Published: December 31, 2021

\begin{abstract}
This paper examines the hadarat tradition as part of integrating Islam with local culture by the AlKatiri Arab group in Tual City. Attendance is a unique ritual that the people of Tual City carry out in celebrating religious holidays such as Eid al-Fitr, Eid al-Adha, weddings, circumcisions, and other religious activities. The community conducts friendship around the village while dancing accompanied by chanting shalawat to the Prophet Muhammad with music (tambourine) in the hadarat. This article uses a qualitative descriptive method, with observations, interviews, and documentation as the data collection techniques. This article shows that the Al-Katiri Arab community played a role in the spread of Islam in Tual City through trade routes and social and cultural approaches. The descendants of the marriage between the Arab al-Katiri group and the Kei Community of Tual City have been considered one part of the Kei community of Tual City. The information was obtained using historical research methods. Appreciating the culture of the Kei people of Tual City as a form of preaching the spread of Islam is the key to the success of the Al-Katiri Arab group living in harmony amid society with local cultural traditions.
\end{abstract}

Keywords: Arabic Al-Katiri; Local culture; Integration; Islamization; Tual City.

\section{Abstrak}

Tulisan ini mengkaji tentang tradisi hadarat sebagai bagian dari strategi mengintegrasikan Islam dengan kebudayaan lokal oleh kelompok. Arab Al-Katiri di Kota Tual. Hadarat menjadi sebuah ritual unik yang dilakukan oleh masyarakat Kota Tual dalam merayakan hari besar keagamaan seperti Hari Raya Idul Fitri, Hari Raya Idul Adha, perkawinan, khitanan, dan kegiatan keagamaan lainnya. Masyarakat melakukan silaturabim mengelilingi kampung sambil menari diiringi lantunan shawat kepada Nabi Mubammad dengan musik (rebana) dalam hadarat. Artikel ini menggunakan metode deskriptif kualitatif, dengan observasi, wawancara, dan dokumentasi sebagai Teknik pengumpulan datanya. Hasil peneltian artikel ini menunjukean bahwa komunitas Arab Al-Katiri berperan dalam penyebaran agama Islam di Kota Tual, melalui jalur perdagangan dan pendekatan sosial dan budaya. Keturunan dari hasil pernikahan antara kelompok Arab alKatiri dengan Masyarakat Kei Kota Tual sudah dianggap sebagai satu bagian dengan masyarakat Kei Kota Tual. Informasi tersebut didapatkan dengan menggunakan metode penelitian sejarah. Menghargai kebudayaan masyarakat Kei Kota Tual sebagai suatu bentuk dakwah penyebaran agama Islam merupakan kunci kesuksesan kelompok. Arab Al-Katiri bidup rukun di tengah-tengah masyarakat dengan tradisi budaya lokal.

Kata Kunci: Arab Al-Katiri; Budaya Lokal; Integrasi; Islamisasi; Kota Tual. 


\section{INTRODUCTION}

In the early stages, the channel of Islamization was trade. In the $7^{\text {th }}$ century to the $16^{\text {th }}$ century $\mathrm{AD}$, busy trade traffic made Muslim traders (Arab, Persian, and Indian) take part in trade from countries in the west, southeast, and east of the Asian continent. Islamization through this trade was very profitable because kings and nobles participated in trading activities. Those who carry out Islamic da'wah and traders who carry out their trade to the indigenous population ${ }^{1}$. Islam in Indonesia spread and developed through trade and followed shipping and trade routes. There is no difference of opinion among experts ${ }^{2}$.

From an economic point of view, Muslim traders had a better social status than most natives, so the natives, especially the daughters of nobles, were attracted to become the wives of these merchants. Before getting married, they were Muslim first. After they had offspring, their environment grew wider, and finnaly Muslim villages, regions, and kingdoms ${ }^{3}$. Some of these Arabs have married local women, thus forming the nucleus of a Muslim community consisting of immigrant Arabs and local residents. According to Arnold, members of this Muslim community also carry out activities to spread Islam ${ }^{4}$.

Islam entered the Moluccas through trade routes in the 15th century. Islam entered through the trade route, because at the beginning of the 15th century Molluca Sohor as a spice archipelago that foreign traders targeted to get cloves and nutmeg. The traders were from AsiaArabic, Gujarat, Chinese, and Javanese and Malay traders who had embraced Islam ${ }^{5}$.

1 Amin Samsul Munir, Sejarah Peradaban Islam (Jakarta: Amzah, 2013), 306.

2 A Daliman, Islamisasi Dan Perkembangan KerajaanKerajaan Islam Di Indonesia (Yogyakarta: Ombak, 2012), 38.

${ }^{3}$ Samsul Munir, Sejarah Peradaban Islam.

4 Azyumardi Azra, Jaringan Ulama Timur Tengah Dan Kepulauan Nusantara Abad XVII \& XVIII: Akar Pembaruan Islam Indonesia, Perenial (Jakarta: Kencana, 2013).

5 Wuri Handoko, "Perniagaan Dan Islamisasi Di Wilayah Maluku,” Kalpataru 22, no. 1 (2013): 17-30.
Before entering outside influences with religious teachings below, the local community first adhered to a primitive belief system; all people in the archipelago have this tradition of life, which is characterized by a nomadic lifestyle and a dynamism belief system. The influence of animism and dynamism began to diminish in the lives of local people after the entry and development of Islam in the Kei Tual Islands. In the historical narrative, the religious teachings that first entered and developed in this area were the teachings of Islam which were under by traders and Arab missionaries who came to trade and spread the teachings of Islam ${ }^{6}$.

The traders and preachers are Sufi teachers, so they have magical abilities and have abilities in medicine. This magical ability can shift the role of shamans in society. The community can accept sufi teachings brought by Arab teachers because there are similarities with the teachings of their ancestors. It is what the Arabs did in carrying out the process of Islamization to the local community when a disease outbreak hit them. The Islamization approach that was carried out at that time was by giving the local community water as a medicine to cure the disease outbreaks they were suffering from, where the water had been recited from fragments of the holy Qur'an'.

The approach taken by the Arab community in spreading Islam does not necessarily eliminate society from its culture but spreads religion through habits carried out by the community. The adaptation model makes the spread of religion in Tual City colorful because it does not clash between religion and culture, it is through the culture that they enter to spread

6 Taufik Abdullah, "Dari Timur Islam Nusantara, Maluku Utara," Jurnal Penelitian Humano 9, no. 1 (2018): 231-40.

7 Andi Al-Katiri (Head of Arab Family Harmony in Tual and Kabupeten Southeast Molluca), Interview, June 23, 2019 
Islam in harmony ${ }^{8}$. One of the traditions that became a forum for integrating Islam and local culture is hadarat. The hadarat tradition has an important role in building social relations in the community consisting of various tribes and cultures in the city of Tual. There is social integration between communities during the hadarat process.

In this study, the method used is descriptive qualitative. Collecting data using observation, interviews, and documentation. The data analysis uses the stages of data reduction, data presentation, and drawing conclusions.

\section{OVERVIEW OF ARAB DESCRIPTION IN THE NUSANTARA}

The territory of Indonesia in classical times was a crossroads of trade traffic networks that connected the East and West Continents. The existence of Indonesia is very profitable in trade, and abundant agricultural products attract the attention of other nations to participate in enjoying these benefits. These economic motives encourage Arab, Dutch, and Chinese communities to make a profit in Indonesia. This trade expedition encouraged Arabs and other nations to come to Indonesia?

The Arabs who currently live in the archipelago more or less come from Hadramaut (South Yemen). Only a few of them came from Maskat, on the shores of the Persian Gulf, from Yemen, Hejaz, Egypt, or from the East coast of Africa, mainly from Hadramaut. The small number of people who came from various countries to the archipelago rarely stayed, if they settled they could immediately mingle with the Arabs from Hadramaut. Most of them are

8 Ismail Suardi Wekke, "Islam Dan Adat: Tinjauan Akulturasi Budaya Dan Agama Bugis," Analisis 13, no. 1 (2013): 27-56.

9 Safira and Ali Haidar, "Perkembangan Komunitas Pedagang Arab Di Surabaya Tahun 1870-1928," Avatara 2, no. 1 (2014): 232-42. travelers, bachelors, who go on adventures to different lands ${ }^{10}$.

The journey from Hadramaut to the Archipelago took months. The journey of the Arabs first had to depart from al-Mokallah or ash-Syihr to Bombay, then to the island of Ceilon (Sri Lanka), and then to Aceh or Singapore. The journey is carried out using a sailing ship. Wealthy Arabs went to Indonesia via Aden and went straight to Singapore on steamboats owned by Europeans who sailed the Aden-Singapore route, making it easy to get to Indonesia. After Singapore, they then headed to the interior of Malacca and the vassal lands of the Dutch government ${ }^{11}$.

Arabs, Arabi, plural; The Arabs who currently live in the archipelago now come from Hadramaut. Only one or of them came from Maskat, on the Persian Gulf, from Yemen, the Hejaz, Egypt, or Africa's east coast. The small number of Arabs who came from these various lands to the Archipelago rarely stayed, and if they did settle they soon mingled with the Arabs from Hadramaut, most of whom were nomads or rather adventurers who quickly disappeared as quickly as they came. One of the national heroes, G.S.S.J Ratu Langie once said that, "it is strange, but understandable that the Arab descent movement was so quickly accepted into the national movement" and she believes that this is not because Arab descent is Muslim. Indeed, history proves that Arab descent has always been part of the resistance movement against the Dutch long before the past, until the era before independence ${ }^{12}$.

The role of Arab traders from Hadramaut, South Yemen. However, we are grateful that, through their trade mission, the Hadramaut

10 Berg, L.W.C. Van Den, Hadramaut Dan Koloni Arab Di Nusantara (Jakarta: Inis, 1989), 1.

${ }^{11}$ Berg.

12 Munawar Kholil, "Naskah-Naskah Islam Papua," Jumantara: Jurnal Manuskrip Nusantara 7, no. 1 (2016): 167-84. 
immigrants asked us to understand and practice the teachings of Islam ${ }^{13}$.

The people of Hadramaut were formed from two and four different groups, namely: (1) the Sayid group, who are descendants of alHusen, the grandson of Nami Muhammad Saw, they have the title Habib (plural: Habaib) and their daughter Hababah, (2) Tribes, called Muqaddim, while the head of the family or branch is called Abu. These leaders are regional rulers. (3) The middle class is a free resident both in the city and in the village. On the shoulders of this group has the power of regional rulers applied. They consist of: a. traders (aqri, plural: qarar), b. craftsmen (ahl as-Sanai), c. farmers (ja'il, plural jailah), d. Helper (khadzam, plural: akhdam).

The tribes found in Hadramaut, starting from the west: (1) descendants of Baraik (alBaraiki), (2) Al-Amr (Al'Amri) they are a Bedouin tribe living in the valleys of Irmah and Duhr. (3) Bait Kindah or descendants of Aswad al-Kindi. (4) Al-Karab bin Al-Karab. (5) the head of the hukman family is also the head of all tribes in Qa'uzah. (6) Al bin Ballais (al Ballaisi). (7) Al Haidara (bin Haidara). (8) Al-Ja'dah (al-Ju'aidi). (9) Al'Ahmud (al-Amudi) or Bani Isa. (10) AzZayabinah (az-Zaibani). (11) Al bin Sa'id (asSa'di). (12) Al Yafi (Al-Yafi'i) or descendants of Yafi bin Himyar. (13) Banu Zannah (az-Zanni). (14) Descendants of Saiban. (15) Al-Humum (alHumumi). (16) Ash-Syanafirah (ash-Syanfari. (17) Al Bajaria (Bajarai) (Muhammad Murtadlo, 2020)

\section{ISLAMIZATION AND EXISTENCE OF THE ARAB AL-KATIRI GROUP IN TUAL CITY}

Before the entry of external influences with the religions brought, the local community first adhered to a primitive belief system. Every community in the archipelago owns this life tradition, which is characterized by nomadic life

13 Ambarak A. Bazher, Islam Di Timor Timur (Jakarta: Gema Insani Press, 1995), 17. behaviors and a dynamism belief system. Belief in spirits or other powers beyond human control is still strong in influencing human life, and belief in dead spirits (ancestors) is very strong in people's lives, animism and dynamism practices are more visible in daily life practices, especially in activities. Hunting, belief in the power of wood, stone, and objects can be used to kill game. In addition, the belief in the existence of sacred places and inhabited by spirits is very strong in the cosmology of the Kei people, the sun and the earth are an inseparable part, where the sun is understood as a male figure and the earth is understood as a female figure ${ }^{14}$.

Islam was the first religion to touch Tual. The Islamic network became increasingly visible when Arab traders set foot in the Molluca area. The merchants in the Islamic network brought a peaceful civilization to the people of the Tual area. The people in Tual welcomed the arrival of these Arab traders with their open nature. They need guidance and guidance from traders. Teaching trade strategies and introducing Islamic culture are basic vehicles for getting sympathizers from the Tual people.

At that time, Islamic broadcasting in Tual City was carried out wisely, appropriately, and with a family approach. The local population quickly accepts Islam and its teachings, and it is easy to spread it to the surrounding villages because it is through marriage between the missionaries/da'i who come with the residents. On the other hand, it is also supported by a culture where the population is still thick with kinship relationships in social life. Through marriage, it fosters brotherhood in a wider family between them. Plus, when a king or leader had embraced Islam, it was easy to influence his people to embrace Islam ${ }^{15}$.

14 Stenly R Loupatty, "Sejarah Kota Tual," Jurnal Penelitian 6, no. 5 (2013): 92-133.

${ }^{15}$ F. Arifin Toatubun, Sejarah Pendidikan Islam Di Kota Tual (Yogyakarta: Bumi Intaran Anggota Ikapi, 2018), 29. 
At that time the condition of the Indonesian nation in the Dutch colony, there were three major religions in the Kei Islands of Tual city, namely Islam, Catholic Christianity, and Protestant Christianity. The religion that first entered the Kei Tual Islands was Islam, which was under the leadership of Arab preachers or preachers, then Catholic missionaries and Protestant zending. However, the teachings of Islam first entered Tual under by Arab traders. This is as conveyed by the chairman of the Arab Family Harmony of the city of Tual Andi alKatiri that: The arrival of Arabs in Tual through trade routes, then settled in the settlement which is currently called Tumbalaka village and traded. In the west of the residence of the Arab community is also inhabited by local residents who have not embraced the belief. When the community was affected by a disease, Arab traders gave water as medicine. When he recovered from the disease and then embraced Islam $^{16}$.

Arab al-Katiri is the largest community of other Arab communities. The hadarat of the Arab community in Tual at that time with trade routes had a huge impact on the local community. This is because the local population still adheres to the belief in anism and dynamism. Of course, the approach is carried out with a pattern of adaptation and a good way so that the local community can receive the religious teachings below. The hadarat of the Al Katiri Arab community is not only in the city center but also in the archipelago in the city of Tual and Southeast Molluca Regency and even several other areas in Molluca Province ${ }^{17}$.

Arriving at the end of the 13th century in 1295, Sultan Isa of Basrah (present-day Iraq) and his wife and son left his birthplace on his own ship, escorted by his Hu Hole, to Indonesia. The

16 Andi Al-Katiri (Head of Arab Family Harmony in Tual and Kabupeten Southeast Molluca), Interview, June 23, 2019.

17 Andi Al-Katiri (Head of Arab Family Harmony in Tual and Kabupeten Southeast Molluca), Interview, June 23, 2019. original destination was Bima and Sumbawa. They arrived in Padang, West Sumatra that same year. The purpose of this voyage is to spread the religion of Islam. Because of that they brought a very sufficient provision. Another name for Sultan Isa is Najamuddin, while his younger brother is Nabata. His younger brother lived in Padang, while Sultan Isa, his wife, and Huhole continued the voyage to the lion in the Lesser Sunda Island (now West Nusa Tenggara), to be precise in Bima Sumbawa in 1296. Then they continued their journey to Luang Island. It is said that Sultan Isa kept the Jin and Dragon ${ }^{18}$.

His wife and maids lived in high places and did not mix with the people of Luang Island in general. Meanwhile, Sultan Isa always preached in various areas and returned once a week. During the 30 years he lived in Luang, Sultan Isa had seven (7) sons and a daughter. The names of the eight children are: (1) Sawe, (2) Korbib Choir, (3) Kanar Babel, (4) Oebtim, (5) Rom Chair, (6) Tawaddan, (7) Sukaro, and (8) daughter named Benwas or Binuas ${ }^{19}$.

One night when their father had just arrived with his pet dragon, his eldest son butchered his father's dragon because his father rarely came home. His father got angry and left. A week later, his father did not return. Then Sawe asked his mother for permission to leave the island of Luang with his younger brothers. His mother allowed and brought provisions for them in the form of very much gold. They left the island of Luang and arrived on the island of Muar (now Dullah island). When they departed, they took the sand from the Luang beach as a condition of farewell, and when they arrived at the southwest coast of Muar, they put the sand they had brought in. This event is called Ngur Ketsoblak. Now this name is become one location name in the city of Tual. They arrived on

18 Ali Fahrudin, "Masuknya Islam Di Maluku Tenggara Dan Peran Masjid Al-Mukarromah Sebagai Basis Penyebarannya," Jurnal Lektur Keagamaan 14, no. 1 (2016): 55-84.

${ }^{19}$ Fahrudin. 
the island of Muar or the island of Dullah in 1330 AD. They were greeted by Toloy Raenfan, the owner of the land of Tual. Arriving at Muar Island, the brothers then split up to the islands around Kei Kecil and Kei Besar. While his sister, daughter Benwas married the Sultan of Bone and from this marriage got a daughter who was later married by the Sultan of Solo ${ }^{20}$.

After the Sawe brothers were in Tual for a few days, they continued their journey back. Sawe went to Kur Utara and became king of Kilmas by Sawe Maswatu. Sawe is an Iraqi dialect Arabic word from the word Sawa Maswatu because it carries a lot of gold ore. Korbib remained in Tual and became the king of Tual. He allied with Letman as Lodar Nara and created the law of Reet Tabal in Tual in 1331. Toloy Renfan named Korbib Choir with Korbib Taher, meaning "Korbib Own this" (meaning Tual land). Regardless of whether this story is original or not, the name Sawe, who has an Arabic-Iraqi dialect, has now become the story of the people in Tual. In understanding local history, folklore is an absolute thing that guides the community. It suffices to mention here that Sawe's exploration is an activity of trade owners (gold ore) who move according to the place and whereabouts of the Tual people.

Kanar Babel went to the island of Danar and became king there with the title Rat Famur Danar. The clan of his descendants is called Hanubun. Babylon comes from Babylon (ancient Iraq). Previously, Danar was ruled by Arnuhu then his kingdom was given to Kanar. Arnuhu gave him the name Famur which means now. So Famur Danar means Kanar Babylon now rules the island of Danar. Kanar Babel married the daughter of Ditsakmas (Ratu Wain) the second child of Rat Ohoivur (king of the Tetoat kingdom. Approximately 30 years later, they both pioneered the enactment of Larvul customary law (such as qishash law) in the Ngursoin area. Larvul means red blood which shows that anyone who

${ }^{20}$ Fahrudin. spills the blood of others (kills), then he must be killed $^{21}$.

Oebtim went to the island of Kei Besar, precisely in Langgiar Fer. In addition to carrying the Koran, he also brought a lot of gold. In the 6th generation from Oebtim, namely Marigun, he just held a da'wah to the island of Tayando together with his brother in Central Molluca, Rat Mavngil who preached to the island of Mastur in the 9th generation from Oebtim, namely $\mathrm{Bal}$ Tubwu'ar, he carried out Islamic da'wah up to Ohoiwait Kei Besar and Elaar Island ${ }^{22}$.

Rom Choir to the island of Har, then married the son of the ruler of the island of Har, namely Lakes Rahalus. When his father-in-law died, he succeeded him and changed his name to Romteur Rahalus. His younger brother Tawaddan went to the island of Aru and later became king as Saman Ujir ${ }^{23}$. The trail of widening their long journey to the Aru Islands is a new part of their knowledge that the affordability of their vision to spread Islamic teachings to all regions in Southeast Molluca is a must. Sukaro to the island of Amar and became king as the king of Amar Skar Tamher Timur. The Sawe brothers, even though when they were only educated on Luang island by their parents, especially their mother, their thoughts were broad and their knowledge of morals, religion, and society was very qualified so that they and their descendants deserved to be kings. The islands they live in are predominantly Muslim².

\section{HADARAT TRADITION IN TUAL CITY}

The people of Tual city consist of people who hold fast to customs, people who hold fast to the maren spirit (the spirit of cooperation), the

21 Weldemina Yudit Tiwery, "Larvul Ngabal Dan Ain Ni Ain Sebagai Pemersatu Kemajemukan Di Kepulauan Kei Maluku Tenggara," Jurnal Sosiologi Pedesaan 14, no. 1 (2018): 8-15.

22 Fahrudin, "Masuknya Islam Di Maluku Tenggara Dan Peran Masjid Al-Mukarromah Sebagai Basis Penyebarannya."

${ }^{23}$ Fahrudin.

${ }^{24}$ Fahrudin. 
spirit of mutual respect for one another, in the Kei language this is known as Ain Ni Ain, (one has the other). Vunt An Mebe Tilur Manut An Mehe Ni Ngifun (we all eggs are the same shape, the same color and both come from the same hen). This term is the culture of the Tual people, which has been maintained and continues to be maintained because it is essential. Among the customs and culture of the Kei Tual people, two things are very taken into account, namely land boundaries and the status of a woman. These two things are precious so that if violated, it can trigger big problems that sometimes can lead to conflicts between groups and villages. At the same time, changes in the social field itself are people who continue to maintain and uphold customs until now ${ }^{25}$.

The traditions and rituals usually carried out by the Muslim community in Tual are diverse. For example, the Prophet Muhammad's birthday celebration is the tradition of reading dhikr. Dhikr is a tradition of reading the book of promise and diba' with a melodious voice and tone (containing praises to the Prophet Muhammad and his companions); this is done in groups and moves from one house to another (take turns). Each group adjusts the implementation. This da'wah movement has become a part of community life in Tual. The impact and influence of ritual traditions on the dynamics of Islam in Tual is very significant and has a wide impact until now. The renewal of Islamic rituals carried out and introduced by them is related to harmonization between sharia and Sufism and the social reconstruction of the Islamic community in Tual $^{26}$.

The Kei people in Tual City consider the existence of Arab Al-Katiri and the Arab community in general as their own family. It can be seen in the various religious activities carried

25 Jacquelin Pattiasina, "Aktualisasi UngkapanUngkapan Tradisional Dalam Kehidupan Masyarakat Kei (Evav) Kabupaten Maluku Tenggara,” 2011, 1-11.

26 Andi Al-Katiri (Head of Arab Family Harmony in Tual and Kabupeten Southeast Molluca), Interview, June 23, 2019. out by the Arab community that always involve the Kei community and the religious activities carried out by the Kei community in Tual city. From the trade aspect, the Arab community of alKatiri has spread to all areas in the city of Tual and has even married local people in the archipelago and has had several descendants to this day. The traditions of the Arab al-Katiri and Arab communities are generally descended from Hadramaut, South Yemen and are still being preserved by their generation in the city of $\mathrm{Tual}^{27}$.

Al-Katiri's Arab community and Arabs in general are very good at building relationships with the Kei people of Tual city. This good relationship can be seen when the traditions carried out by the Kei people of Tual city are: the Ye Lim tradition (donations, alms), and $\mathrm{Nit} \mathrm{Ni}$ Wang (praying for the dead, marriage, aqiqah, circumcision, haji). This tradition is a medium of gathering for the Kei people in Tual city ${ }^{28}$. (Interview, Ahmad Tamherwarin, 2019).

Unknowingly the image of Islam and Arabs has begun to spread among the Tual people. Almost all the assimilation movements carried out are trade and da'wah, summarized in social relations. It is almost impossible to separate and differentiate between the Arabs of Al-katiri and which of the Tual people in the present condition. Such an attitude results from continued trade politics (Interview, Andi al-Katiri, Chair of Arab Harmony in Tual, 2019).

One tradition that is popular and exists today is hadarat. Hadarat is a unique habit carried out by the people of Tual City, in celebrating Islamic holidays such as: Eid al-Fitr, Eid al-Adha, weddings, circumcisions, and other religious activities. The community conducts friendship around the village, which parents follow, teenagers and even children walking around the village while dancing to the accompaniment of

27 Andi Al-Katiri (Head of Arab Family Harmony in Tual and Kabupeten Southeast Molluca), Interview, June 23, 2019.

28 Ahmad Tamherwarin (Kei Traditional Figure), Interview, June 25, 2019. 
chanting prayers to the Prophet Muhammad SAW, his friends with music (tambourine) in the hadarat ${ }^{29}$.

Hadarat is an Islamic culture taken from Sheikh Abdul Qadir Jailani. The blows of hadarat in each area are very diverse. This diversity as its characteristic can provide participants enthusiasm in carrying out the hadarat ${ }^{30}$

Friendship activities that are often carried out in implementing hadarat at the end of Eid alFitr are a form of respect and appreciation for ancestral heritage that the local community has long practiced. For example, parents and teenagers are not allowed to leave the village until the activity is completed when the implementation begins. On the other hand, it encourages the younger generation and children to understand the purpose of hadarat itself.

Therefore, the people in the city of Tual still consider the tradition of hadarat to be an important tool in religious life. So that in this study several positive things were obtained from the implementation of the hadarat in the city of Tual, which became social sanctions, including:

a. When the community is not involved in the implementation of the hadarat, the participants together carry the person concerned to the beach to be bathed. This looks normal but has a big social impact on the community so they do not repeat it. The community has carried out this condition since the beginning of its hadarat until now. ${ }^{31}$

b. Muslims have been fasting in the holy month of Ramadan and culminating in Eid al-Fitr, for 7 days the public must attend hadarat. If someone do not attend the hadarat, it is recommended to fast for 7 days. For 7 days it is interpreted as the day of the fall of ma'rifat. Then on Eid al-Adha, for those who do not carry out the hadarat, fast for 3 days so that 40 days are even like humans. This tradition is still maintained until now. ${ }^{32}$

c. Attendance is an important means of selfdiscipline because the above is carried out according to time, for example in the morning starting at 07.00 until finished.

d. Hadarat contains the value of togetherness, family, which the Kei language of the city of Tual, Molluca Province, is called maren (mutual cooperation). Hadarat can resolve social conflicts that are still rooted in the tradition of hadarat in local communities.

Hadarat is also often performed in Islamic carnivals. People gathered in the courtyard of the mosque in the rice fields waiting for the start of the event. They then walked in a long line followed by a troupe of tambourines and accompanied by the shalawat singer who was in the back position. The accompaniment of the hadarat group was slow because from time to time they stopped hearing the beats of the tambourine and prayer and usually the participants followed while doing movements in the hadarat.

\section{INTEGRATION OF ISLAM AND LOCAL CULTURE}

The meeting between Islam and local culture will create an interaction, forming a new culture or institution in religion. It can not be denied related to the interaction that the religion of Islam is rabmatan lil alamin. The meaning of rahmatan lil alamin can be interpreted as Islam can be accepted anywhere, anytime, and to anyone. The concept of rahmatan lil alamin can cross the ages and this region can be understood by everyone and can accept all forms of its teachings without that person having to understand Arabic even though Islam was born in that region. This meeting of Islam with local

\footnotetext{
${ }^{29}$ Rusli Kilwo (Traditional Figure), Interview, 2019.

${ }^{30}$ Rusli Kilwo (Traditional Figure), Interview, 2019.

31 Sanusi Ahmad (Traditional Figure), Interview,
} 2021.
${ }^{32}$ Idham Ohoiwer (Traditional Figure), Interview, 2021. 
culture also shows that Islam can show its existence.

The spread of Islam was successful because there was an interaction or assimilation of Islamic culture and local culture. The tensions can occur if Islamic culture is forced to replace local culture. Sometimes this is done with the excuse of enforcing Islamic law or grounding worship rituals. For example, Arabic is the only language, even though of the 25 prophets, only one prophet spoke Arabic ${ }^{33}$.

One thing in common between Islam and local culture is that they both have rituals that live in society. The intelligent decision made by Islamic da'i is to ground Islam by actualizing it with rituals that live in the community without changing the substance of worship and shari'ah in Islam itself and uprooting traditions that have been embedded in society. The Islamic community in Tual knows very well about the upper and lower limits of Islamic teachings that need to be maintained and which need to be updated with local culture. In terms of formality, it can be argued between Islam and local culture. However, in pure monotheism, Islamic teachings cannot be mixed with local culture because Islam is present and grows in a social environment and takes into account customs as part of its da'wah ${ }^{34}$.

The Islamic community in Tual knows very well about the upper and lower limits of Islamic teachings that need to be maintained and which need to be updated with local culture. In terms of formality, it can be argued between Islam and local culture. However, in pure monotheism, Islamic teachings cannot be mixed with local culture.

Based on this, Islamic attitudes towards local culture are divided into three: (1) Accepting and developing a culture that is following Islamic principles and is useful for glorifying human life.

33 Andi Al-Katiri (Head of Arab Family Harmony in Tual and Kabupeten Southeast Molluca), Interview, June 23, 2019.

34 Philipus Tule and et.al, Wacana Identitas Muslim Pribumi NTT (Maumere: Penerbit Ledalero, 2015), 163.
(2) Reject traditions and cultural elements contrary to Islamic principles. 3) Leave it alone, as in the way of dressing as long as it does not violate Islamic principles.

The interaction of Islam and local culture is an effort to see the dynamic relationship between Islam and various values and concepts of life preserved and inherited and seen as a way of life by the related community.

In the daily life interactions of the people of Tual City and Southeast Molluca, there are three adhesive values called:

1. The philosophy of "Ain Ni Ain Hira Ni Fo Hira Ni It Did Fo It Did, " is interpreted as a form of brotherhood.

2. The philosophy of "Foing Fo Kut Faun Fo Banglu”. United we stand, divided we fall, and

3. The philosophy of "Vuut Ain Mehe Ni Ngivun Manut Ain Mehe Ni Tilur" means that all Kei Tual and Southeast Molluca people come from one lineage.

As already explained, one of the adhesive values that exist in the Kei community of Tual City and Southeast Molluca Regency is the value of kinship and brotherhood. Therefore, it makes it easier for the Kei people of Tual City and Southeast Molluca Regency to interact and establish good relations with other tribes, including the Al-Katiri Arab community in Tual and Southeast Molluca District. The community is no longer marked by gathering an ethnic group in a certain mukim space. However, it is a mixture of various ethnic groups. It is especially the case in the social and economic growth centers in a national and regional commitment. This amalgamation gave birth to a new cross-ethnic interaction pattern. This cross-ethnicity dominates the fraternal life of the Kei people in Tual. So, that the adaptation of togetherness with anyone outside of himself becomes the luggage of the descendants of the Tual people.

The Kei community of Tual city can also interact in a good and healthy manner with people from outside Kei such as: Arab, Javanese, Padang, Bugis and Makassar people, East Nusa 
Tenggara and West Nusa Tenggara, as well as Buton and Ambon. Although there are many differences, the Kei Muslim community and the non-Kei community (Arabic, Javanese, Padang, Bugis and Makassar, East Nusa Tenggara and West Nusa Tenggara, as well as Buton and Ambon) Muslims can interact with each other, living permanently in the city of Tual and carrying out activities, interactions between cultures on a daily basis. This is influenced by many factors, including belief, marriage, education, and trade

Local culture is generally associated with the legitimacy of the power of local rulers. Therefore, the stronger influence of local authorities, the greater the possibility of an accommodative attitude of Islam towards local culture. This tendency is still considered normal because it is in line with Islamic teachings, as long as the local culture does not insult human values. Local culture is adopted as an instrument to "wrap" the contents of Islam, and is made as part of Islamic teachings as long as it is following the spirit of glorifying humans. The thick color of local Islam in Indonesia also illustrates the quality of Islam itself. Islam was not revealed to "force" humans to worship God, but for the good of humans themselves ${ }^{35}$.

If everyone has absorbed society's cultural traditions, the behavior framed in the form of the tradition has almost become automatic and without realizing it has been socially accepted as well. Tradition will give birth to an accommodative spirit of neighborliness. And will reconstruct a new consciousness in a humanistic character. This humanistic nature will eventually result in a new encounter, namely an encounter that gives appreciation to others in a relationship of social life. The law of Larvul Ngabal (red blood and spear from the island of Bali) applies in this relation.

35 Suryan Suryan, "Toleransi Antar Umat Beragama: Perspektif Islam," Jurnal Ushuluddin 23, no. 2 (January 2017): 185, https://doi.org/10.24014/jush.v23i2.1201:185-200.
In the Kei culture of Tual City and Southeast Molluca Regency, it was found that there are many valuable values for living together, such as: kinship, kinship, brotherhood, obedience to the law and superiors, and mutual help without distinction of religion, but because of "one blood".

These values are revealed in the law of Larvul Ngabal (red blood and spear from the island of Bali). In the relationship between humans and which are specifically tied to the life philosophy of the Kei people of Tual City and Southeast Molluca Regency, called: "ain ni ain". "manut ain mehe ni tilur, vunt ain mehe ni ngivun", (we are one, one unit, one pillar that cannot be separated) and that is why in the realm of the soul, acknowledging one's conscience is important to educate people to know their position among others.

Tual City and Southeast Molluca Regency, have local cultures that are still ongoing, for example: (1) Adat Sasi (prohibition), (2) Maren (mutual cooperation), (3) Caste, is divided into three: first, mel-mel (highest caste), second, ren (middle caste), third, riri (lower caste).

\section{CONCLUSION}

Hadarat became a unique habit carried out by the people of the city of Tual, in celebrating the greatness of Islam such as: Eid alFitr, Eid al-Adha, weddings, circumcisions, and other religious activities. The community conducts friendship around the village, which parents follow, teenagers and even children walking around the village while dancing to the accompaniment of chanting prayers to the Prophet Muhammad SAW, his friends with music (tambourine) in the hadarat. Al-Katiri Arabs played a crucial role in entering and developing Islam in Tual. They have a huge role in the da'wah of Islam and the process of Islamic education. The Al-Huria Grand Mosque is located in the center of Tual, close to shops and markets and housing for the Al-Katiri Arabs. AlHuria Grand Mosque, located on Tumbalaka 
street, Tual city, is usually called the Great Mosque. Of course, the Al-katiri Arab community had a role in building this mosque. Molluca is not only known as a spice-producing area. However, the development of Islam in Molluca in the early days could not be separated from the hard work of the preachers in teaching the Koran to people who embraced Islam. In the cities of Tual and Southeast Molluca, studies on Islamic history are still limited due to lack of evidence (documents). So, studies on Islam continue to be carried out in order to provide understanding to the public about its relation to Islam in Eastern Indonesia.

\section{REFERENCES}

A. Bazher, Ambarak. Islam Di Timor Timur. Jakarta: Gema Insani Press, 1995.

Abdullah, Taufik. "Dari Timur Islam Nusantara, Maluku Utara." Jurnal Penelitian Humano 9, no. 1 (2018): 231-40.

Azra, Azyumardi. Jaringan Ulama Timur Tengah Dan Kepulauan Nusantara Abad XVII \& XVIII: Akar Pembaruan Islam Indonesia. Perenial. Jakarta: Kencana, 2013.

Berg, L.W.C. Van Den. Hadramaut Dan Koloni Arab Di Nusantara. Jakarta: INIS, 1989.

Daliman, A. Islamisasi Dan Perkembangan KerajaanKerajaan Islam Di Indonesia. Yogyakarta: Ombak, 2012.

Fahrudin, Ali. "Masuknya Islam Di Maluku Tenggara Dan Peran Masjid Al-Mukarromah Sebagai Basis Penyebarannya." Jurnal Lektur Keagamaan 14, no. 1 (2016): 55-84.

Handoko, Wuri. "Perniagaan Dan Islamisasi Di Wilayah Maluku." Kalpataru 22, no. 1 (2013): 17-30.

Kholil, Munawar. "Naskah-Naskah Islam Papua." Jumantara: Jurnal Manuskrip Nusantara 7, no. 1 (2016): 167-84.

Loupatty, Stenly R. "Sejarah Kota Tual.” Jurnal Penelitian 6, no. 5 (2013): 92-133.

Pattiasina, Jacquelin. "Aktualisasi UngkapanUngkapan Tradisional Dalam Kehidupan Masyarakat Kei (Evav) Kabupaten Maluku
Tenggara," 2011, 1-11.

Safira, and Ali Haidar. "Perkembangan Komunitas Pedagang Arab Di Surabaya Tahun 1870-1928." Avatara 2, no. 1 (2014): 232-42.

Samsul Munir, Amin. Sejarah Peradaban Islam. Jakarta: Amzah, 2013.

Suryan, Suryan. "Toleransi Antar Umat Beragama: Perspektif Islam.” Jurnal Ushuluddin 23, no. 2 (January 2017): 185. https://doi.org/10.24014/jush.v23i2.1201.

Tiwery, Weldemina Yudit. "Larvul Ngabal Dan Ain $\mathrm{Ni}$ Ain Sebagai Pemersatu Kemajemukan Di Kepulauan Kei Maluku Tenggara." Jurnal Sosiologi Pedesaan 14, no. 1 (2018): 8-15.

Toatubun, F. Arifin. Sejarah Pendidikan Islam Di Kota Tual. Yogyakarta: Bumi Intaran Anggota Ikapi, 2018.

Tule, Philipus, and et.al. Wacana Identitas Muslim Pribumi NTT. Maumere: Penerbit Ledalero, 2015.

Wekke, Ismail Suardi. "Islam Dan Adat: Tinjauan Akulturasi Budaya Dan Agama Bugis." Analisis 13, no. 1 (2013): 27-56.

\section{Interviews}

Ahmad Tamherwarin (Kei Traditional Figure), Interview, June 25, 2019

Al-Katiri, Andi (Head of Arab Family Harmony in Tual and Kabupeten Southeast Molluca), Interview, June 23, 2019

Idham Ohoiwer (Traditional Figure), Interview, 2021.

Rusli Kilwo (Traditional Figure), Interview, 2019.

Sanusi Ahmad (Traditional Figure), Interview, 2021. 